\title{
Applying Science Process Skills in Understanding Chemical Equilibrium Through Experiment
}

\author{
*Friska J. Purba, Debora S. Sitinjak \& Kelly Sinaga \\ Pendidikan Kimia/FKIP - Universitas Pelita Harapan - Tangerang 15811 \\ Received 12 March 2021, Revised 15 April 2021, Accepted 18 May 2021 \\ doi: 10.22487/j24775185.2021.v10.i2.pp78-86
}

\begin{abstract}
Students from Teachers College coming from various regions causes variations in the cognitive, affective, and psychomotor level. Some of them have a difficulty that leads to misconception in understanding the content in chemistry, particularly on chemical equilibrium. One of the ways to comprehend that content is by conducting experiments. This study aims to apply science process skills in understanding chemical equilibrium through the experiment method. This research also helps students in their experiments in which their ability is shaped to reach the level of application. Through experiment method, science process skill will develop and give a good response in giving action both in cognitive comprehension and ineffective as well as psychomotor level. The research method used is pre-experimental with a OneGroup Pre-Post test Design. The result showed N-gain was 0.7 , which classified high categories and science process skills showed good categories. The final result of this research was that students would be able to understand chemical equilibrium better by applying science process skills with an experiment.
\end{abstract}

Keywords: Science process skills, experiment method, chemical equilibrium

\section{Introduction}

Humans created by God are different from other creations. Humans are given reason, mind, and mind; this is what distinguishes humans from other creations. So that God gives freedom to humans in exploring their thinking ability to return to glorify God. However, the freedom given by God is developed by man according to his own will. This is what often makes humans deviate from God's will and grieves God's heart so that it causes humans to fall into sin. The redemption that God made with His death on the cross was done only once, and it applies to all generations. This redemption was given by God freely to mankind, but that does not mean that humans did not respond to this redemption. Humans continue to do the right thing as a form of response to God's work. One of the right actions is managing science as a responsibility as creation. As stated Saputri \& Djumhana (2020) science is a way of expressing facts, concepts, and ideas that exist in the universe. In this case, humans explore all the truths contained in this science so that the truth is fully understood. Education is a container that can be used by humans in seeking the truth. Through education, humans can also respond to real actions in understanding what is created. With the existence of education, the truth is increasingly being presented so that the quality of the human self also increases. With the presence of education, human resources are also getting better and competent.

Based on the student educational backgrounds at Teachers College (TC), most of them come from various regions in Indonesia, that their ability to understand lessons also varies. Some students are cognitively high, and some are still lacking. Some of the students had difficulty understanding the material of chemical equilibrium because they could not see the principle of equilibrium in everyday life. The reason for this is that learning at the high school level related to this material has no real impact. There are still many TC students from several areas who have difficulty accessing chemistry learning. This is because the learning that is presented at the high school level is limited to theoretical learning. This greatly affects the understanding of knowledge by the students themselves, there are even some who do not understand the concept, and some have misconceptions. The same thing was conveyed by Hikmah et al. (2018) in the reaction rate concept, that students' understanding of this concept is still low at the microscopic level and need to also pay attention to attitude and psychomotor.

Seeing that the topic of chemical equilibrium greatly affects advanced materials such as acid-base

*Correspondence:

Friska J. Purba

e-mail: friskajulianapurba@gmail.com

(c) 2021 the Author(s) retain the copyright of this article. This article is published under the terms of the Creative Commons Attribution-NonCommercial-ShareAlike 4.0 International, which permits unrestricted non-commercial use, distribution, and reproduction in any medium, provided the original work is properly cited. 
concept, solubility, and solubility product therefore it is necessary to do a way to embed concepts that can be done by the students themselves. With the diversity found in TC, it is necessary to apply an approach so that the goals of education and student understanding are evenly distributed. The aim of this education is also in line with the vision and mission of the chemistry education study program, namely to prepare teachers in the field of chemistry studies who have true knowledge. The knowledge presented is not sufficient in the scope of theoretical understanding alone but must be able to be applied in everyday life. Children will learn from what they do like the philosophy of learning by doing. Through what is experienced and done, science becomes more refined and easier to understand. One of the efforts to harmonize this knowledge simply and to be able to apply the knowledge presented is utilizing the experiment's method. The experiment is a method that is appropriate to reconcile what is theoretically presented. In line with Lestari \& Diana (2018) students can build meaningfully based on what is presented based on theory and can connect it in the experiment to solve science problems.

According to Rusman (2017) understanding in experimental activities also still expects their ability to the application stage as written in Bloom's taxonomy regarding thinking skills, communication skills, research skills, application skills in line with the achievement of student graduate profiles, namely being able to study the implications of developing or implementing technology science that pays attention to and applying the values of life following their expertise based on scientific principles, procedures, and ethics to produce constructive solutions, ideas, and designs or criticism of art. The term "experimental method" is a process skill to develop about the natural surroundings by using scientific methods and scientific attitudes in solving problems encountered in everyday life. Meanwhile, according to Whitton (2015), the experimental method is a method in which students become direct researchers of certain phenomena and how things work to be able to answer and determine why certain phenomena occur in certain ways. The experimental method is a method of presenting learning in which students who carry out experiments must experience what they are doing, observe an object and gain learning experience in overcoming problems that occur (Nursalam \& Effendi, 2008). To conclude the experimental method is appropriate because students experience and see for themselves what they are doing so that this can provide a complete understanding of the concept of learning that is followed, and these students can overcome learning problems encountered in everyday life day. The experimental method is very helpful for students because according to Nursalam \& Effendi (2008) this method can increase the ability of students to be able to learn independently and solve problems.
According to Maulana et al. (2015) the experimental method can develop students' science process skills. There is a significant increase in learning outcomes through the experimental method (Subekti \& Ariswan, 2016).

To reach the understanding level, students need to develop their skills as science process skills. With the skills they have, students who generally do practicum can improve their understanding of chemistry. As stated by Susanto (2013) that the skills possessed must be able to improve skills in thinking, acting, and behaving, and it will give a good response in providing good action levels of cognitive, affective, understanding, and student psychomotor. When students are fully skilled, they will develop creativity and cooperation in doing an experiment. So, this research was conducted to see more clearly the importance of students' science process skills in understanding chemical equilibrium with the experimental method. For example, the purpose of the experimental method itself is that experiments can provide space for students to take opportunities to lead learning and to demonstrate their knowledge and understanding. The learning method using the experimental method can develop students' science process skills. This is because theoretical understanding is closely related to experimental activities, as suggested by Sujana (2014). The same thing was conveyed by Sumarni et al. (2016) experiment in chemistry learning is an important approach to get a better understanding and application of chemistry. Laboratory-based learning helps students find facts, theories learned in lectures.

As a student, someone should be able to integrate skills, knowledge, and attitudes to build a scientific concept. Therefore, educators can develop their science process skills: the ability to observe, measure, make conclusions, classify, predict, and communicate. The same thing was written by Kurniawati et al. (2016) that students could be actively involved in scientific learning both individually and in groups by using science process skills. According to some of the expert opinions above, the researcher concluded that science process skills were carried out to reveal theoretical truth and facts and could be seen and experienced in the process by requiring skills in managing both.

Indicators of science process skills are explained by several experts: according to Hisbullah \& Selvi (2018) consist of observing, classifying, measuring, communicating, interpreting data, predicting, using tools, conducting experiments, and concluding. The same indicator is written by Kurniawati et al. (2016), namely observing, predicting, making hypotheses, planning experiments according to procedures, carrying out experiments, asking questions, communicating, and concluding data from discussion results. Whitton (2015) stateed that the experimental method can be passed in several steps, such as: questioning certain phenomena or information, making hypotheses, conducting 
experiments, drawing conclusions (verifying, refuting, or building hypotheses). The same thing was expressed by Nurhayati et al. (2019) consisting of the ability to observe, predict, measure, classify, communicate, and conclude.

From some of the expert opinions described above, this study uses the following indicators: 1) Observation: (a) Students use sensory tools while conducting experiments, (b) Students record all experimental data and information presented. 2) Measuring (measurement): (a) Students use appropriate measurements in each experiment, (b) Students can use measuring devices when experimenting by the procedures carried out. 3) Classifying: Students classify experimental data based on their characteristics. 4) Interpreting observations (inference): Students can make hypotheses when conducting experiments. 5) Communicating (communication): (1) Students can transfer information to their group mates, and (2) Students can systematically compile experimental reports. 6) Conclude (conclusion): Students can draw conclusions based on the experiments carried out.

\section{Methods}

The flowchart of this study is shown in Figure 1. This study uses a pre-experimental research method with One-Group Pretest-Posttest Design. This experimental design was seen like in Figure 2 (Dwianto et al. 2017).

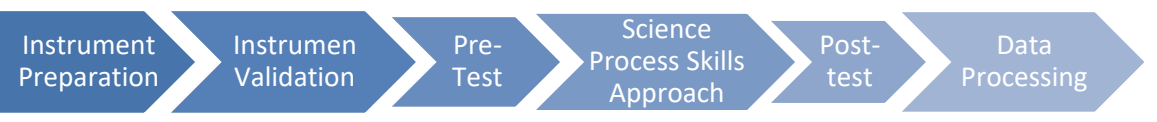

Figure 1. Research flowchart

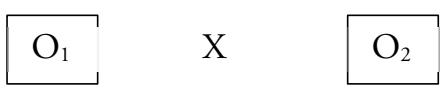

Figure 2. One-group pretestposttest design

The students will be given a pre-test to measure their pre-knowledge continued by the experimental method and post-test (Ekawati et al., 2018).

\section{Preparation stage}

In this stage, students have worked on experiment journals which will make it easier to conduct experiments and write theories that will be included in the lab report regarding the topic of chemical equilibrium. This is to minimize the misconceptions that occur when understanding the theoretical basis and seeing the experiments being carried out.

\section{Experimental stage}

Students do a pre-test to get information about the basic abilities or knowledge about the experiment. This is useful in seeing the level of understanding they have and seeing the cognitive abilities that are presented. Next, students carry out experiments based on journals that have been worked on in the preparation stage, and at this stage, the lecturers continue to assist students. After conducting a series of experiments and having provided an explanation related to the experiment being carried out, students did a post-test to see the final ability of students in participating in experimental activities that had been carried out.

\section{Final Stage}

Students systematically process the data presented during the experiment and are outlined in the lab report (were taken for science process skills). The sample in this study amounted to 16 people. Selection considerations are due to the taking of sample members from the population without paying attention to the existing strata in this population (Ekawati et al., 2018). The instruments used in this study were test and observation sheets. The data collection technique in this study uses data collection tools in the form of pre-test and post-test, tests related to the topic of chemical equilibrium, and observation sheets related to science process skills. The tests and observation sheets are adjusted to answer the objectives of the experiment, namely: 1) Studying the factors that affect chemical equilibrium. 2) Determine the equilibrium constant of a reversible reaction using the colorimeter method. This goal is also following some of the identification of difficulties experienced by students in understanding chemical equilibrium (Indriani et al., 2017). Based on interviews conducted by Astuti et al. (2018), the topic of chemical equilibrium is very difficult to study because it is not interesting, because the material is abstract, and it is added that learning is only theoretical without adding creative methods. 
The test has been validated by 2 experts and is declared fit for use. Data analysis was used descriptively. Thus, it is necessary to see the understanding of the content before and after the experimental method is applied by being analyzed using normalized gain based on Hake's equation 1 (Nurussaniah et al., 2017).

$$
g=\frac{\text { skor post test }- \text { skor pre test }}{\text { skor maksimum - skor pretest }}
$$

Based on the formula, normalized $\mathrm{N}$-gain interpreted to get the implementation of science process skills can help the content understanding with experiment method. Table 1.

Criteria for normalized $\mathrm{n}$-gain is shown in

Table 1. Normalized n-gain criteria

\begin{tabular}{cc}
\hline $\mathrm{N}$-gain & Interpretation \\
\hline $0.7<\mathrm{g} \leq 1$ & High \\
$0.3<\mathrm{g} \leq 0.7$ & Medium \\
$0 \leq \mathrm{g} \leq 0.3$ & Low \\
\hline
\end{tabular}

To measure the science process skills, the data was descriptively analyzed in which the raw data was arranged into the easier explanation.

This study is also using modified likert scale "1-strongly disagree"; "2-disagree"; "3-agree" and "4-strongly agree" (Subekti \& Ariswan, 2016). Interval data presented from the observation sheet were processed using simple calculations. The interval data is analyzed by calculating the average answer based on the score of each student, in line with Permendikbud No. 53 of 2015 calculated using the formula:

$$
\text { Score }=\frac{\text { student's score }}{\text { maximum score }} \times 100
$$

Researchers used the guidelines for the success criteria to interpret the percentage presented according to Tampubolon (2014) as shown in Table 2.

Table 2. Success indicator

\begin{tabular}{ccc}
\hline Interval & Category & Criteria \\
\hline $81-100 \%$ & $\mathrm{~A}$ & Very good \\
$61-80 \%$ & $\mathrm{~B}$ & Good \\
$41-60 \%$ & $\mathrm{C}$ & Enough \\
$21-40 \%$ & $\mathrm{D}$ & Less \\
$0-20 \%$ & $\mathrm{E}$ & Very lass \\
\hline
\end{tabular}

\section{Results and Discussion}

Based on the results of research that has been conducted in the practical activities of students of the Chemistry Study Program, along with the recapitulation of data observation of each indicator using test instruments.

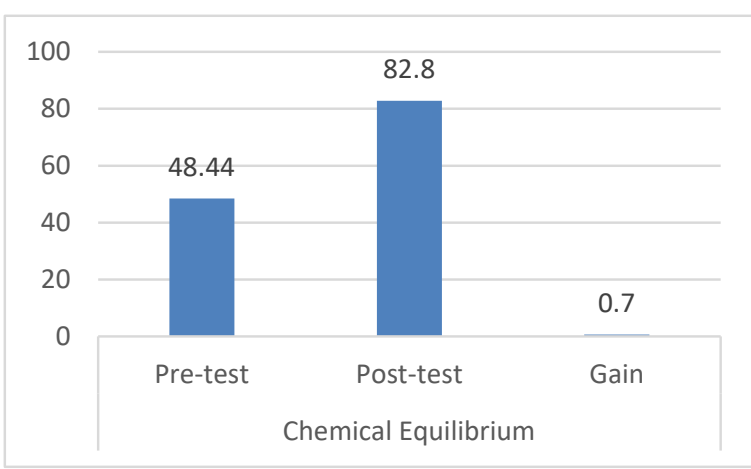

Figure 3. Chart of total average pre and post test and $\mathrm{n}$-gain scores 


\section{Test instruments based on experimental methods}

By using the assumption test normality liliefors test at the level of significance for $\alpha=0.05$ on chemical equilibrium material. Based on the data presented above, the average understanding of the chemical equilibrium through experiment method is in a high category. This is based on the gain value presented that the value $\mathrm{g}=0.7$.

\section{Questionnaire Data Observation}

The recapitulation of data was presented in Table 3. The display of data related to improvement and decline is different from indicators of science process skills. Based on the data was presented in the table above based on the observation sheet presented that measuring skills with $97.75 \%$ is the highest skill and classifying skills with $68.5 \%$ being in the lowest category.

Referring to Figure 4, the percentage of science process skills aspect by the students in the good category, which measuring skill in the high level and classified in the low category.

Table 3. Questionnaire data observation

\begin{tabular}{ccccccc}
\hline \multirow{2}{*}{ Exp. } & \multicolumn{5}{c}{ Science Process Skills } \\
\cline { 2 - 7 } & 1 & 2 & 3 & 4 & 5 & 6 \\
\hline Chemical equilibrium & 88.5 & 97.75 & 68.5 & 71.5 & 86.5 & 74 \\
\hline
\end{tabular}

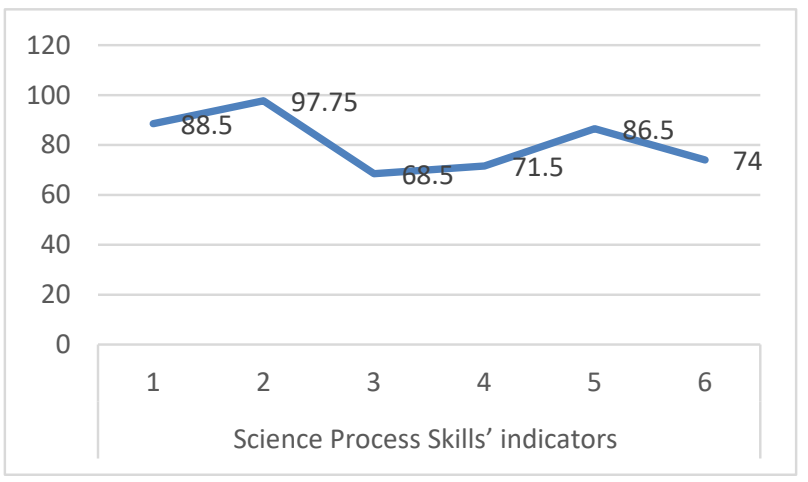

Figure 4. Questionnaire data observation

The data was presented in the test instrument results above show that experimental methods can help students' science process skills, specifically in understanding chemical equilibrium materials. If reviewed more deeply that, the student can take a closer look at the material, which can help for the understanding of the content. Similar to Apriliani et al. (2015), the experimental method invites students to conduct experiments and check students' beliefs in the understanding presented so as to understand the concept and be more active in learning. The application of experimental methods by reviewing the skills of the student science process skills has improved on the implementation of pre-test and post-test. This improvement is also closely related to the explanation of lecturers after students conduct experiments; in addition to being able to make direct observations, students are re-equipped with explanations of the experiment process implemented.

Through the activity stage conducted during the experiment, the preparatory stage can equip students to understand the material before conducting the experiment; in this stage, students are looking to write a journal based on the practicum module that has been given at the beginning of the meeting. At this stage, students are also looking for various references related to chemical equilibrium. This initial understanding is what provides students with initiating practicum. Moving on from the initial understanding, there are several things that have been prepared to be answered during practicum.

The implementation stage is the stage of students conducting experiments; in this stage, first, check the initial ability through the implementation of the pre-test. The provision of this question is very important for researchers to ensure understanding before conducting experiments so that researchers can provide or clarify the initial understanding that they have. After the pre-test, students conduct experiments following a journal that has been prepared at the preparatory stage.

During the experiment, students can be more skilled and can use the tools and materials that have been prepared. Students work independently and collaboratively based on their group. At this stage, students are very enthusiastic because they can 
conduct their own scientific experiments and investigations. In theory, students already understand the topic of factors that affect chemical equilibrium. On the occasion of conducting experiments, students can clearly see the relationship between factors that affect chemical equilibrium. It can associate theory and perform directly related equilibrium shifts. With the addition/reduction of concentration, students can clearly see the process of shifting equilibrium itself by looking at the intensity of the resulting color. In principle, students get a clearer understanding of equilibrium shifts. It added that students could also use the colorimeter used in determining equilibrium constants. On the understanding of theory has been given calculations related to the determination of equilibrium constants.

However, the determination of these equilibrium constants can also be answered through experimentation. More deeply, it is equipped with the principle of light that affects the value of absorbance so that students can determine equilibrium constants based on the concentration value of the footage and the absorption value presented based on observations. Through this experiment, students' skills are getting better at investigating problems scientifically. In addition to the skills gained indirectly, the ability to collaborate among students is also getting better. After conducting an overall experiment, students had a discussion together in a group. The discussions created can help their understanding because diverse observations can further complement understanding, so the role of the group has a good impact.

The role of peers in conducting experiments with groups, there is space and time for students to discuss and hone each other's skills. It can also be seen from the experimental activities conducted that the activities are well organized, both in data collection/observation, conducting experiments, or reporting the results of experiments. It is also supported that human nature is not separated from the community. The community can help with a clearer understanding. The perceived community in the given group has a good impact, especially in understanding the chemical content. As conveyed by Maulana et al. (2015), learning methods using experiments with the help of peers can develop science process skills so that the ability to understand content can be more pronounced; this can be seen from the ability of students to work independently and in groups so that students themselves can solve scientific problems.

After the discussion, a post-test was also conducted in measuring the ability presented during the administration of experimental methods. Whatever the treatment provided, it can answer the purpose of this study. Based on the results presented, the treatment by giving the right experimental method is done where students look to better understand the chemical equilibrium more clearly and see from the post-test value described in the diagram. After the post-test, students perform the final stage of reporting what has been presented during the experiment in the form of scientific reports.

Scientific reports are also answered in the indicators of science process skills. Based on the indicators presented from the chart that has been displayed, there is a difference in value for each indicator. The first indicator is observing skills. Observing skills are seen when students practice and rewrite their observations into journals and reports. Based on the instrument of science process skills test, observing skills fall into the excellent category; students can observe events scientifically based on observations related to chemical equilibrium. It is also proven that these skills are categorized in an excellent category, where students are able to see a shift in equilibrium with the treatment of changes in the concentration of the solution added to each tube that has been provided.

The second indicator is measuring skills. Measuring skills relate to the use of appropriate tools in retrieving and measuring a material needed in an experiment. For the indicators as a whole, measuring skills are the highest skill, and these skills are also in the excellent category. As seen also in the observation sheet during the experiment, students have become more skilled in using measuring instruments; this is because students are used to working in the laboratory, so they are used to using measuring instruments and can read the analysis.

The third indicator is the skill of classifying. Classifying skills are skills in grouping experiment data based on their characteristics. Students are still unable to group and compare the observations they presented based on the characteristics of the data. This indicator is the lowest indicator of all indicators of science process skills, which although still fall into the category of good. On this indicator, students have not been able to classify the standard solution concentration with samples. Students were found negligent in writing in the results of observations of sample absorbance values presented based on the absorbance presented. Another factor is that the tool used in measuring this absorption is still first operated by students, also because the available tools are limited in number so that only some students do a practicum, others only observe.

The fourth indicator is interpreting skills. Indicators of interpreting skills are in a good category; this indicator includes providing explanations supported by the theory relevant to the observation data presented, processing observation data to answer questions contained in the module, providing explanations about the differences in experimental data with theory data, and finding patterns from the observations presented. Based on the observation sheet given, students are still less able to provide scientific reasons about why there are differences in data results in experiments with theory.

This is probably because the theory of the experiment has not been studied in-depth, making 
it difficult for students to find the actual theory. The same is also presented that there are students who have not processed the data to answer questions in the practicum module. This can be observed from the answers given in the answer section of the question there are still not precise.

The fifth indicator is communication skills and is in the excellent category. The measurable communication activity is that students communicate their observations into various forms such as tables, and writings. Students analyze each observation data and present it into the table or writing needed in accordance with the purpose of the experiment. Another activity that shows indicators of communication skills is that students are able to discuss observations with group friends in the preparation of practicum reports. Students who took absorbance measurements were found to have a lack of understanding of what was observed, so in discussing the results of their observations to their groupmates, both in explaining what they observed and discussing the results of the experiment, it was found that their groupmates did not understand the whole. However, this indicator has been answered after being given an explanation by lecturers and researchers. Students better understand the use of colorimeters so as to determine equilibrium constants with this method and can pour into experimental reports systematically and provide explanations of observation results based on relevant theories.

The sixth indicator is the concluding skill and being in a good category. Concluding skills are the skills to draw conclusions based on discussions made in accordance with the purpose of the experiment. In this category, students have not exactly drawn conclusions based on the discussion. From the reports that were done, some students still used the discussion on theory, not based on what was stated in the discussion. This shows that students are less accustomed to carrying out scientific investigations.

Overall the science process skills from the results of this study are in a good category but still need to be sharpened more scientifically so that by repeating the process, science process skills will develop so that scientific investigation can be honed. The same thing was conveyed by Lepiyanto, (2014) in the analysis of science process skills that a scientific approach is needed in developing skills.

Science process skills in learning are things that educators, both teachers, and lecturers must apply because basic science is not just science that consists of scientific products in the form of facts, principles, concepts, and theories, but also a process that requires a variety of scientific skills and attitudes to achieve and understand the scientific products (Nurtika et al., 2017).

Students can more easily understand the material being taught in the presence of concrete situations and conditions that can be practiced directly (Yulasti et al., 2018). This science process skills can be improved by using experiment-based learning methods. Experimentation is part of science learning, and especially in the practical course of the basics of chemistry, experimental methods are needed to develop analytical skills and skills in conducting various experimental methods and skills in instrumentation.

From the analysis of each indicator of science process skills, it appears that science process skills applied through experimental methods can provide a comprehensive understanding for students. Although there are some indicators of low student science process skills, the experimental method has provided a real experience for students to work in the laboratory and explore the theories learned in the classroom. Students are trained to have a scientific attitude in solving problems that arise in practicum. Learning is also more fun because students can see and interact directly with the knowledge they learn by doing practicum activities.

This is in line with the research results Lestari \& Diana (2018) that practicum-based learning has a positive impact because students do practical work directly. It can make students more enthusiastic and accompanied by better learning outcomes. Practical-based learning can also make students more active and happy. Similar research conducted by Subekti \& Ariswan (2016) that the application of experimental methods to improve cognitive learning outcomes and science process skills.

The results of the study concluded that there was a significant increase in learning outcomes in cognitive aspects and science process skills in class X students at SMA Negeri 9 Yogyakarta with a guided inquiry learning model through the experimental method. The application of the practical-based science process skills approach has a sufficient percentage of value due to the formation of these skills repeatedly based on the experiments carried out. In line with this statement Rani (2017) stated that real activities are important in linking in life, enabling students to better understand lessons, which gain knowledge, and develop psychomotor skills that include observation, measurement, classification, recording data, creating hypotheses, using data and gaining the ability to create, change and control variables, and do a scientific experiment.

\section{Conclusions}

From the results of the research that has been done, it can be concluded that the application of science process skills can help understand chemical content, especially chemical equilibrium material, based on experimental methods. Students can develop their science process skills and can be developed for other experiments. Further research will be refined regarding indicators of science process skills that still have to be instilled by students so that experiment-based learning can include cognitive, affective, and skill understanding.

\section{Acknowledgments}

Thanks to Pelita Harapan University for funding this research. We have received research 
funding with number P-011-FIP/V/2019 and have used it to use research to investigate student science process skills with experimental methods in practical basics of chemistry.

\section{References}

Apriliani, S., Budiarti, I. S., \& Lumbu, A. (2015). Penggunaan analogi dalam pembelajaran fisika melalui metode eksperimen topik aliran arus listrik untuk meningkatkan penguasaan konsep siswa kelas X SMA YPPK Taruna Dharma Kotaraja. Jurnal Pendidikan Fisika dan Keilmuan, 1(1), 14-19.

Astuti, S., Danial, M., \& Anwar, M. (2018). Pengembangan LKPD berbasis PBL (problem based learning) untuk meningkatkan keterampilan berpikir kritis peserta didik pada materi kesetimbangan kimia. Chemistry Education Review (CER), 1(2), 90-114.

Dwianto, A., Wilujeng, I., Prasetyo, Z. K., \& Suryadarma, I. G. P. (2017). The development of science domain based learning tool which is integrated with local wisdom to improve science process skill and scientific attitude. Jurnal Pendidikan IPA Indonesia, 6(1), 23-31.

Ekawati, N. W., Iswari, R. S., \& Lisdiana. (2018). The influence of scientific independence towards students' content analysis and science process skills on cell metabolism topic. Jurnal Pendidikan IPA Indonesia, 7(4), 420-427.

Hikmah, N., Saridewi, N., \& Agung, S. (2018). Penerapan laboratorium virtual untuk meningkatkan pemahaman konsep siswa. EduChemia (Jurnal Kimia dan Pendidikan), 2(2), 186-195.

Hisbullah., \& Selvi, N. (2018). Pembelajaran ilmu pengetahuan alam di sekolah dasar. Makassar: Aksara Timur.

Indriani, A., Suryadharma, I. B., \& Yahmin. (2017). Identifikasi kesulitan peserta didik dalam memahami kesetimbangan kimia. Jurnal Pembelajaran Kimia, 2(1), 9-13.

Kurniawati, D., Masykuri, M., \& Saputro, S. (2016). Penerapan model pembelajaran inkuiri terbimbing dilengkapi lks untuk meningkatkan keterampilan proses sains dan prestasi belajar pada materi pokok hukum dasar kimia siswa kelas X MIA 4 SMAN 1 Karanganyar tahun pelajaran 2014/2015. Jurnal Pendidikan Kimia (JPK), 5(1), 88-95.

Lepiyanto, A. (2014). Analisis keterampilan proses sains pada pembelajaran berbasis praktikum. BIOEDUKASI: Jurnal Pendidikan Biologi Universitas Muhammadiyah Metro, 5(2), 156161.

Lestari, M. Y., \& Diana, N. (2018). Keterampilan proses sains (KPS) pada pelaksanaan praktikum fisika dasar I. Indonesian Journal of Science and Mathematics Education, 1(1), 49-54.

Maulana., Djuanda, D., Hanifah, N., Sujana, A., Gusrayani, D., Aeni, A. N., Julia., Jayadinata,
A. K., Irawati, R., \& Lichteria P. R. (2015). Ragam model pembelajaran di Sekolah Dasar. Bandung: UPI Sumedang Press.

Nurhayati., Saputri, D. F., \& Assegaf, S. L. H. (2019). Pengembangan Instrumen tes keterampilan proses sains pada materi fisika untuk siswa Sekolah Menengah Pertama. Edukasi: Jurnal Pendidikan, 17(2), 145-158.

Nursalam, \& Effendi F. (2008). Pendidikan dalam keperawatan. Jakarta: Salemba Medika.

Nurtika, A., Kadaritna, N., \& Tania, L. (2017). Pengembangan instrumen asesmen kognitif berbasis KPS materi larutan elektrolit dan non elektrolit. Jurnal Pendidikan dan Pembelajaran Kimia (JPPK), 6(3), 549-560.

Nurussaniah., Trisianawati, E., \& Sari, I. N. (2017). Pembelajaran inkuiri untuk meningkatkan keterampilan proses sains calon guru fisika. Jurnal Ilmiah Pendidikan Fisika AlBiRuNi, 6(2), 233-240.

Rani, S. A., Wiyatmo, Y., \& Kustanto, H. (2017). Concept attainment worksheet to enhance concept knowledge and science process skills in physics instruction. Jurnal Pendidikan IPA Indonesia, 6(2), 326-334.

Rusman. (2017). Belajar dan pembelajaran berorientasi standar pendidikan. Jakarta: Kencana.

Saputri, A. E., \& Djumhana, N. (2020). Keterampilan Proses sains dan sikap ilmiah mahasiswa PGSD dalam belanjar ilmu pengetahuan alam (IPA). DWIJA CENDEKIA: Jurnal Riset Pedagogik, 4(1), 35-43.

Subekti, Y., \& Ariswan. (2016). Pembelajaran fisika dengan metode eksperimen untuk meningkatkan hasil belajar kognitif dan keterampilan proses sains. Jurnal Inovasi Pendidikan IPA, 2(2), 252-261.

Sujana, A. (2014). Dasar-dasar IPA : Konsep dan aplikasinya. Bandung: UPI Press.

Sumarni, W., Wardani, S., Sudarmin, \& Gupitasari, D. N. (2016). Project based learning (PBL) to improve psychomotoric skills: A classroom action research. Jurnal Pendidikan IPA Indonesia, 5(2), 157-163.

Suryani, \& Hendryadi. (2015). Metode riset kuantitatif: teori dan aplikasi pada penelitian bidang manajemen dan ekonomi islam. Jakarta: Prenada Media Group.

Susanto, A. (2013). Teori belajar dan pembelajaran di sekolah dasar. Jakarta: Prenada Media Group.

Tampubolon, S. (2014). Penelitian tindakan kelas: untuk pengembangan profesi pendidik dan keilmuan. Jakarta: Erlangga.

Whitton, D. (2015). Teaching and learning strategies. Australia: Cambridge University Press.

Yulasti, N. I., Rohadi, N., \& Putri, D. H. (2018). Peningkatan keterampilan proses sains dan 
pemahaman konsep melalui model learning cycle $5 \mathrm{E}$ berbantuan virtual lab pada materi usaha dan energi. Jurnal Kumparan Fisika, 1(3), 76-82. 